\section{Zum Einfluß der Cryohydrolyse in Trifluoressigsäure auf den DP von Cellulose}

\section{Fengel; M. Przyklenk}

Institut für Holzforschung. Universität München, Winzererstraße 45, 80797 München

Subject: Freezing of cotton linters in water and diluted TFA reduces only slightly the degree of polymerization (DP) whereas in $100 \%$ TFA the DP drops significantly. Such a pretreatment may facilitate the total hydrolysis of cellulose containing samples.

Material und Methoden: Baumwoll-Linters wurden in Wasser. $30 \%$ iger und $100 \%$ iger Trifluoressigsäure (TFE) über Nacht gequollen, anschlicßend mit flüssigem Stickstofl tiefgefroren und bis zum aächsten Tag im Gefrierschrank $\left(-25^{\circ} \mathrm{C}\right)$ aufbewahrt. Nach dem Auftaten wurde die TFE im Vakuum-Rotationsverdampfer abgedampfi und der Rückstand mil Wasser ausgewaschen. Im Waschwasser wurde der Glucosegehalt bestimmt (Zuckeranalysator). Der Rückstand wurde nach einer Gefriertrocknung nitriert und zur viskosimetrischen Bestimmung des Durchschnitts-Polymerisationsgrads (DP) verwendet.

Ergebnisse: 1. Das Einfrieren in Wasser und in verdünnter TFE hat nur einen geringen EinfluB auf den DP von Baumwoll-Linters (Tabelle). 2. Mit 100\%iger TFE wird der DP jedoch drastisch reduziert. 3. In keinem der wäßrigen Extrakte konnten monomere Zucker nachgewicsen werden. 4. Eine Vorbehandlung von cellulosehaltigen Proben durch Einfrieren in 100\%iger TFE kann deren Totalhydrolyse erleichtern.

Sapotnitsky, S. A., A. T. Porubova 1992, Holzforschung 46, 245248. Philipp. B.. K. J. Linow 1965, Zellst. Papier 14.321 326. Fengel, D., G. Wegener. A. Heizmann. M. Przyklenk 1978, Cell. Chem. Technol. 12,31 37.

Tabelle. Cryohydrolyse von Baumwoll-Linters

\begin{tabular}{ll}
\hline Einfriermedium & DP \\
\hline Ausgangsmaterial & 1870 \\
- Wasser & 1770 \\
$-30 \%$ ige TFE & 1600 \\
$-100 \%$ ige TFE & 380 \\
\hline
\end{tabular}

\section{Information on cocos wood-polymer composite}

M. Lawniczak*, D. Chovanec, M. Supin**

* Agricultural University. Wojska Polskiego 38/42. PL 60-637 Poznan, Poland

** Technical University in Zvolen, Masaryka 24,96053 Zvolen. Slovakia

Subject: Physical and structural studies on cocos wood-polymer composites were performed.

Material and method: For this study cocos wood (Cocos mucifere L.) has been used provided by Prol. A. Frühwald (Hamburg). This wood was modified with styrene monomer according to the method elaborated by Lawniczalk (1975).

Results: The big differences in density between stem periphery $\left(980 \mathrm{~kg} / \mathrm{m}^{3}\right)$ and pith zone (middle $\left.70 n \mathrm{e}\right)\left(312 \mathrm{~kg} / \mathrm{m}^{3}\right)$ are connected in parallel with the increasing percentage of thinwalled parenchymatic tissue from periphery to the pith. Part of parenchym has turned into sclereids (Fig. 1).

After polymerization. density of outside layers increased by 11.7 per cent $\left(1095 \mathrm{~kg} / \mathrm{m}^{3}\right)$, and density of the inside layers went up by 58.6 per cent $\left(495 \mathrm{~kg} / \mathrm{m}^{3}\right)$. In this way the differences in density decreased and raised the strength of cocos wood. The polymer can be found mainly in thinwalled parenchym and it penetrated lumina of sclereids (Fig. 1). It can be found also in the intercellular big voids of parenchymatic tissue (Fig. 2). Polystyrene did not fill big vessels in collateral bundles. We assume that this may be due to capillary forces in cocos wood.

Commonly, cocos wood is used after cutting and often bears traces of decay. Treatment with polystyrene can not only strenghten the palm wood, but may also destroy the fungi in this wood.

Lawniczak, M.: Holz Roh-Werkstoff 33 (1975) 222-230
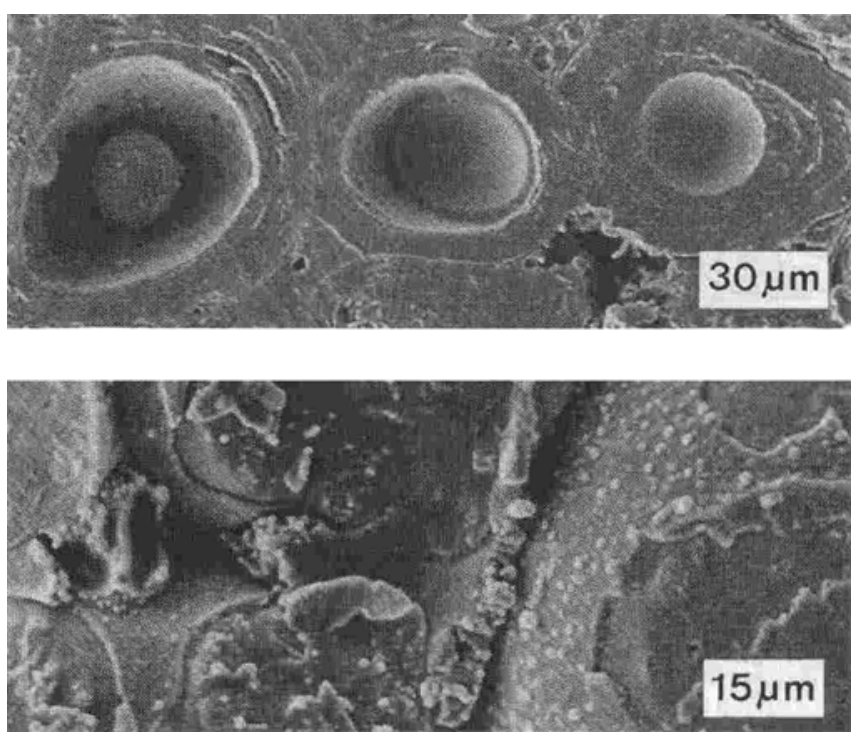

Fig. 1, 2. Are too block 